Mansoura University

Faculty of Education

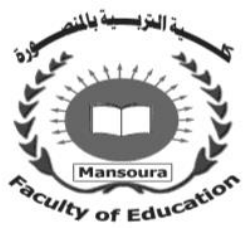

Conflict Talk in Noah Baumbach's Marriage Story: An Interdisciplinary Study of the Challenging Negotiations of Divorce

\author{
By \\ Dr. Hanaa Mohamed Hilmy El-Gindy \\ Lecturer of Linguistics \\ Dept. of Foreign Languages \\ Faculty of Education \\ Mansoura University
}

Journal Of The Faculty Of Education-Mansoura University

No. 114 -April. 2021 


\title{
Conflict Talk in Noah Baumbach's Marriage Story: An Interdisciplinary Study of the Challenging Negotiations of Divorce
}

\author{
Dr. Hanaa Mohamed Hilmy El-Gindy \\ Lecturer of Linguistics \\ Dept. of Foreign Languages \\ Faculty of Education \\ Mansoura University
}

\begin{abstract}
Conflict talk is the talk that accompanies conflicts. It is the outcome of negotiations of disagreement in confrontational interaction. This research paper deals with conflict talk in Noah Baumbach's Marriage Story. It offers an interdisciplinary study of the challenging negotiations of divorce in the data for analysis. The study is interdisciplinary as it derives from conversation analysis, discourse analysis, and pragmatics. It suggests for the analysis of data a theoretical framework inspired by Jef Verschueren's Linguistic Adaptation Theory. It proposes that language use is a dynamic process of linguistic choice (1999). The framework has two facets: structural and strategic. The research paper claims that a conflict is a communicative context of adaptability where people make language selections that generate this talk. The paper attempts to figure out the causes of conflict talk and show how people adapt their behavior to conform structurally and strategically to the conflicting context at hand. The paper concludes that dynamic negotiations between disputing language users during conflict talk can reach positive ends, e.g., resolutions and agreements, if they adapt their language choice towards convergent rather than divergent processes of interaction.
\end{abstract}

Key Words: Conflict talk; Linguistic Adaptation Theory; structural phases of negotiation in conflict talk; linguistic strategies of conflict talk; Marriage Story.

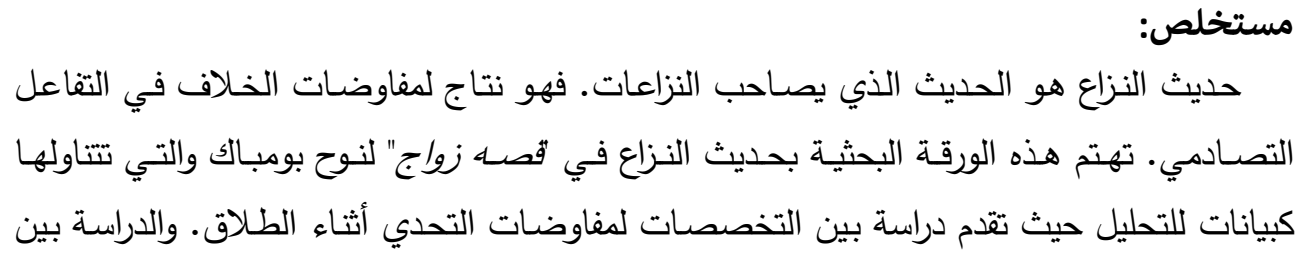




$$
\begin{aligned}
& \text { التخصصـات لكونها مشتقه من تحليل المحادثة، وتحليل الخطاب، والتداوليـة. ولتحليل البيانـات، } \\
& \text { تقترح هذه الورقة البحثية اطارا نظريا مستلهم من نظريه التكيف اللغوي لجيف فيرشورن. فتقترض فئه }
\end{aligned}
$$

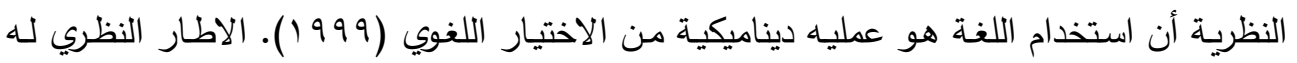

$$
\begin{aligned}
& \text { شقين: بنائي، واستراتيجي. وتقترح هذه الورقة البحثية أن النزاع هو سياق تواصلي هن هن النيات التكيف حيث }
\end{aligned}
$$

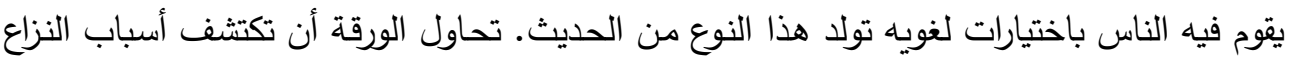

$$
\begin{aligned}
& \text { وتوضـح كيف تستطيع النـاس أن تكيف تصـرفاتها بنائيا واستراتيجيا مـع سياق النزاع في الكـلام. } \\
& \text { وتخلص الورقة الى أن النزاعات الديناميكية بين مستخدمي اللغة المتنازعين أثناء حديث النزاع ممكن }
\end{aligned}
$$

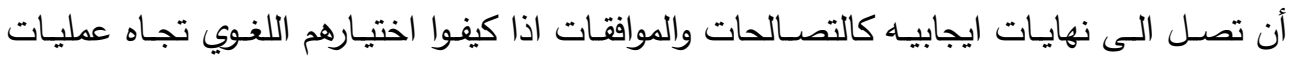

$$
\begin{aligned}
& \text { التفاعل القائمه على التقارب و ليس التباعد. }
\end{aligned}
$$

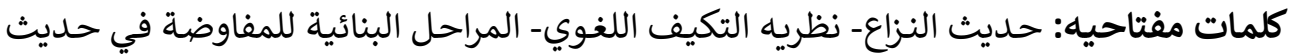

$$
\begin{aligned}
& \text { النزاع- الاستراتيجيات اللغوية في حديث النزاعـ نظيه النزاع- قصه زواج. }
\end{aligned}
$$

\section{1- Introduction:}

Conflict talk is the talk through which the participants have different conflicting standpoints against each other on specific issues in conversational interaction. It has merited a lot of research in different fields of knowledge, e.g., communicative psychology, sociology, rhetoric, philosophy, and linguistics. The researchers dealt with it from unilateral points of view, each in their own field. Consequently, they labeled it differently. Formerly, linguists considered it an instance of "disorderly discourse" (Briggs, 1996). So, they did not offer a linguistic study of it between adults. This was also due to the difficulty of gathering data of real conflicts among adults in instances of face-to-face confrontational interactions. Brennis and Lein (1977) were mainly interested in it between children and labeled it "verbal disputes". Boggs (1978) called it "contracting routines". Eisenberg and Garvey (1981) named it "adversative episode". Then, other linguists shifted their attention to conflict talk between children, on one hand, and adults, on the other hand. They called it "oppositional argument" (Goodwin, 1983, 1990a, 1990b; Schiffrin, 1985; Goodwin and Goodwin, 1987, 1990). Pomerantz (1984) labeled it "disagreement". Antaki (1994) named it "quarrel". It was Grimshaw (1990) who called it "conflict talk". Early researchers were concerned with conflict talk as a structured unit and named it "aggravated disagreement" (Kotthov, 1993). Then, they discussed the situational context of the conflict (Bilmes, 1988; Greatbatch, 1992; Baym, 1996; Myers, 1998). Lately, they dealt with conflict talk as a 
medium to threaten one's face and to construct ideology. Hence, they dealt with it within the lines of "aggravation- mitigation continuum" (Wood and Kroger, 1994; Dersley and Wootton, 2001).

The point here is that these myriad researchers handled conflict talk as a static product. They did not offer an interdisciplinary study of it as a dynamic process of language choice, based on the adaptability to variables, which sustains the identities, stances, intentions, and expectations of its users. To compensate for the shortage in previous studies, this paper applies Verschueren's pragmatic model of Adaptation to variables. It claims that language users make an adaptive relationship between the communicative context and the structure of their conflicts to keep pace with the physical world, the social world, and the social world around them. It shows that conflict talk is a conscious negotiable language choice of adaptability from the variable options that people have in language. It calls to mind Nelson's recognition that "the meanings of terms are tied to their use, and those uses are multiple due to their use in multiple contexts"(2001: 19). The paper offers a linguistic analysis of conflict talk in Noah Baumbach's Marriage Story from an interdisciplinary perspective. The paper derives mainly from discourse analysis, conversation analysis and pragmatics. In so doing, it deals with the challenging negotiations between spouses during divorce as real instances of conflict talk or discourse. These negotiations of divorce are challenging because they stimulate argumentation, refutation, and rebuttal (Heritage, 2002: 1439). Here, the words 'talk' and 'discourse' will be used interchangeably.

Folger, Poole and Stutman (1997: 73) point out that "conflicts move in negative directions because people are incapable of diagnosing the conflict and altering their behavior. ... They can be trapped in their interaction patterns." The paper aims to diagnose conflict talk as a dynamic linguistic choice of adaptation to the communicative context, pinpoint its causes, and to change people's behavior towards it. In the light of adaptation theory, the paper deals with conflict talk structurally and strategically. The paper focuses mainly on the contextual correlates of adaptability. Structurally speaking, it presents three different phases of conflict talk: initiation, escalation, and termination. Strategically speaking, it offers a matrix of the linguistic strategies that work as makeups for the conflict and enhance its heat. As there is a shortage of real and natural data for analysis, the researcher uses a script of a modern American movie, Noah Baumbach's Marriage Story, as data for analysis. This movie is considered the nearest instance of conflict discourse. It is about the story of a marriage that falls 
apart as result of the escalation of conflict talk and the disruption of any attempts of resolution.

\section{2- II. Noah Baumbach's Marriage Story:}

Noah Baumbach is a modern American producer, writer, co-writer, and director. He was born in 1969 in Broklyn, New York. He descends from an artistic family. His parents are both film critics. He is the outcome of a turbulent family with a Jewish father and a protestant mother. He has undergone all the suffering that a child might have because of the separation of his parents. Not all his siblings do belong to his father and mother. Some of them belong to his father only. Noah himself has experienced divorce and the troubles for custody. He married twice. He had a boy from his first marriage and a girl from the second one. In addition to many other works, his two movies, The Squid and the Whale in (2005) and Marriage Story in (2019) brought him great success and fame. These two movies are concerned with the family that falls apart because of divorce. The Squid and the Whale focuses on the suffering of children after their parents' separation. Marriage Story spots light on the process of divorce itself. It is mainly about the suffering of parents, accompanied with expensive tricky lawyers, in courts to gain custody of their children. It shows that in these cases, both conflicting parties, namely the husband and wife, not their lawyers, are losers. Instead of saving money to improve the future of their son, they spend it on clever lawyers. The parents lose time, effort, and money.

The importance of Marriage Story is three-fold. Firstly, it is a movie which is inspired by the personal life story of the author who himself belongs to a family of divorced parents. Hence, the audience can easily perceive the truth of the story and feel for its lead characters. Baumbach said: "I couldn't write an autobiographical movie if I tried... The movie is not autobiographical; it's personal" (Ugwu, 2019). Secondly, it discusses a subject matter, divorce, which has become very common nowadays in Western and Arab societies. The movie highlights the idea of 'me too'. Each one can imagine himself/herself in such a divorce story. Thirdly, it contributes to the great success of its author as a writer and director. It won the prize for the best screenplay and was nominated for six other famous awards, e.g., academy awards.

Although the movie is called "Marriage Story", it is not about a romantic love story that ends with marriage. Contrarily, it is about the story of the divorce of a couple, Charlie and Nicole, who used to live and work together for ten years. Charlie, the husband, is a self-made stage director. $\mathrm{He}$ 
is inspired, dedicated and talented. He is busy in making his fortune in New York. Nicole, the wife, is a lead actress in his plays. Before marriage, she spent all her life in Los Angeles. She was more famous than her husband. But after marriage, she left Los Angeles, where she was expected to continue her success, and moved with him to New York. She sacrificed her personal career and became a member in his team- work. With the passage of time, her fame diminished as an individual figure and her husband's fame increased. As the movie unfolds, we find them sitting at a mediator's office, in Los Angeles. He was attempting to save their marriage by asking each one of them to write the good parts in his partner. Unfortunately, he fails. Nicole refuses to read her paper, claiming that she does not like what she wrote about her husband. The crucial point in their conflict is that whereas Charlie wants to stay in the east coast because he considers himself a New Yorker, Nicole wants him to move with her to the west coast where she receives an offer of pilot series in Los Angeles. She feels that this work in Los Angeles is a chance to regain her fame and identity which are lost during this marriage. She takes their son, Henry, with her to Los Angeles and decides to settle there. She refuses to come back to New York. She thinks that this is the time for Charlie to sacrifice a little bit and fulfill his old promises to her, before marriage, that they will settle in Los Angeles. Nicole, feeling neglected and forsaken, decides to leave Charlie. On the other hand, Charlie feels that Nicole is stealing his son from him. So, instead of giving her a big hug and promising that things are going to change for her sake, he discusses divorce with her. Charlie does not exert an effort to help this marriage to proceed forward at the time of this storm. They agree together that they will make it a clear divorce with no lawyers between them.

Bit by bit, with the interference of family and friends, Nicole's character starts to change. She resorts to law and hires a feminist lawyer, Nora, to speak for her with Charlie about their divorce project. Following the tricky advice of her lawyer, who is divorced also, Nicole makes her sister serve Charlie the divorce papers in Los Angeles. Not only does Charlie find himself obliged by law to hire a lawyer to answer her pleas back, but he must proceed in the case in Los Angeles, not in New York. Hardly, he finds an old lawyer, called Bert Spitz. We know that this lawyer has gone through the divorce experience three times. With the passage of time, the relationship between Nicole and Charlie turns from bad to worse. Charlie fires his lawyer, Bert, and hires another one who is cleverer and more expensive. The new lawyer is called Jay Marotta. On seeing Jay, 
instead of Bert, in court, Nora perceived the feeling of competition. Consider the following extract with Nicole:

"Nora: Charlie shouldn't have done this.

Nicole: What do you mean? Where's Bert?

Nora: It means everything we've agreed upon is now off the table.

Nicole: But, we've got LA, right-

Nora: Not with this Jay Marotta representing him. This is a street

fight. now. And I'm going to have to ask for things we wouldn't

normally ask for. We will need as much leverage as possible to

negotiate with.

(Nora rises with a pinched smile.)

This system rewards bad behavior. - - and greats Jay." (Baumbach, 2019: 107).

In their attempts to win against each other, the lawyers of each party go to more extremes. They turn the divorce conflict into a marathon of dirt and loss. They manipulate all their dirty and dishonorable ways to win and get custody of the son. Being exhausted, physically and spiritually, Nicole and Charlie decide to talk together about their current situation. Instead of setting things in the right position and getting into terms with each other, they blamed each other, threw their gloves in each other's face and said things that should never be said. They reached a termination point from which it was impossible to come back. After this big fight, we realize that both are committing a great mistake. We cannot take one part against the other one. Divorce becomes the bitter solution that never lulls their pains.

\section{3- III. Research Questions:}

This research paper attempts to answer the following questions:

1. What are the causes of conflict talk in the light of Verschueren's theory of Adaptation?

2. What are the structural phases of negotiation in conflict talk? How can people start, escalate, and terminate conflict talk?

3. What are the linguistic strategies that occur in face-to-face conflict discourse? And how do they index challenge and disruption in interaction?

\section{4- IV. Theoretical Preliminaries:}

\section{5- IV. a. The Linguistic Adaptation Theory:}

The Linguistic Adaptation Theory goes back to a Belgian pragmatist called Jef Verschueren. He believes that "using language must consist of the continuous making of linguistic choices, consciously or unconsciously, for language- internal (i. e. structural) and/or language- external reasons" (1999: 
55- 56). His model is mainly applied to communication, language teaching, interpretation, and translation. As conflict talk is an instance of language selection, it becomes feasible to apply this theory to it. In his pragmatic theory, Verschueren deals with language choice from cognitive, social and culture perspectives (1999: 76- 101). For him, whenever language users communicate, they are obliged to make deliberate language choices to achieve adaptation to the target context with respect to the physical, social, and psychological world.

His Adaptation Theory focuses on three interrelated properties of language: variability, negotiability, and adaptability (ibid: 59- 61). Variability and negotiability are prerequisites for adaptability. Variability means that language offers variable options to its users to choose from during their communication. Negotiability is the property of language that shows that language choice is a flexible dynamic process. Adaptability is property of language that shows that language users can produce negotiable language selections from the variable options available to them to adapt to the context. Conforming to these properties of language, language users can produce correct language choices in conjunction with their communicative needs.

Verschueren (ibid: 76) suggests four focal points for the study of adaptability, namely, context, structure, dynamics, and salience. The contextual correlates of adaptability include the communicative context and the linguistic context. The communicative context incorporates language users responsible for the production and interpretation of the utterance (utterer and interpreter) and the non- linguistic context (the mental world, the social world, and the physical world). The linguistic context includes the channel and the neighboring utterances in the text or the linguistic context. The structural objects of adaptability in addition to the contextual correlates of adaptability explain the scope of adaptability. In other words, language choice is adaptable to the context and the structures of the text. The dynamics of adaptability represent the dynamic, not static, processes of negotiation involved in the generation and interpretation of meaning. Salience reflects the status of adaptability. It shows that language users make their language choices consciously and unconsciously according to their psychological motivations during the adaptation process. To recap, adaptation is a mutual process of language choice between language users where they conform context to structure. Context and structure represent the place at which the dynamic process of language choice happens with different degrees of awareness of the adaptation process. 


\section{6- IV. b. Communicative Framing Theory:}

Communicative Framing Theory is a theory on interpretive sociology. It came to light in the 1960. It is another theory of conflict that marks the relationship between language choice and language users as negotiators during conflicts. For this theory, communication is the means through which disagreement is conducted and managed (Hocker and Wilmot, 1991). It shows that language users make linguistic selections to focus on a specific topic and neglect another. This process of conflict negotiation adds to the complexity of the conflict as it generates other conflicts inside the main conflict. It assumes that frames are the basis for communicative structure. Drake and Donohue (1996: 302) define frames as "transient communicative structures disputants build around conflict issues during turn at talk". They (ibid: 298) elaborate that "management" controls interaction. Management of these communicative structures sustains "integrative" processes of interaction whereas mismanagement of them produces "distributive" processes of interaction (Deutsch, 1973). Controlling communication is a matter of tact choice. Drake and Donohue point out that integrative strategies include tactics like slowing interaction, formulating nonreciprocal responses, limiting alternatives, linking issues, or building trust. Distributive strategies embody tactics like fault-finding, hostile demands, and topic changes (1996: 299).

Relying on Wehr's (1979) conflict map, Drake and Donohue (1996: 303) identified four communicative categories of conflict frames: fact, interest, value, and relational. Fact frames focus on unbiased assessments of reality. Interest frames cover future wills and hopes. Value frames includes acceptances and rejections according to social conventions and morals. And relational frames revolve about the feelings between the conflicting parties. In the light of communicative framing theory, the conflicting parties can adjust their topics, through the process of language choice, to the settled frames and propose next topics also.

\section{7- IV. c. Speech Accommodation Theory:}

Speech accommodation theory (Giles, et al., 1987) is a theory on conflict talk that sustains communicative framing theory. It handles the connection between the "convergence" and the "divergence" of frames in forming cooperative or in-cooperative contexts. It claims that speakers should accommodate their participation to the frames that are assigned to them by their interlocutors in speech. For this theory, frames are the limits that language users should not trespass. Convergence occurs when language users embrace the same limits. Consequently, it brings out positive results, 
e.g., respect, social approval, and interpersonal involvement. It creates a cooperative context appropriate for integrative negotiations. On the other hand, divergence gives prominence to the variability from the others. It results from the rejection of the limits between the participants. It sustains negative interpersonal effects, e. g., antagonism and uncooperativeness. To sum up, frame convergence leads to agreement between disputant parties whereas frame divergence leads to an impasse. Convergence leads to integrative ends. But divergence produces distribution and dissociation.

\section{8- IV. b. Conflict Talk:}

As its name suggests, conflict talk is the talk that takes place during conflicts. It is "any type of verbal or non- verbal opposition ranging from disagreement to disputes, mostly in social interaction" (Kakava, 2001: 650). Schiffrin (1985: 37) claims that oppositional discourse is known as "discourse through which one or more speakers support openly disputed positions". Conflict talk is mostly regarded as a negative aggressive talk (Grimshaw, 1990). However, it can be seen as a friendly act with positive effects. Nelson (2001: 17) supports this view by stating that, sometimes, terms are inappropriately substituted for each other, e.g., conflict, competition, negotiation, dispute, bargaining and mediation. He claims that meanings are related to their contexts. So, the interlocutors attempt to select the term which suits their linguistic contexts. Following Verschueren's adaptation theory, conflict talk is a conscious dynamic process of language choice where conflicting participants select negotiable variables to realize adaptation to the context of the conflict. It is the outcome of negotiations of disagreement in confrontational interaction. In the light of the adaptation theory, the conflict is the wider communicative context at which language users manipulate the properties of language, to be specific, variability, negotiability, and adaptability, to cope with the linguistic context and produce structures adaptive to their communicative needs. The process of language choice occurs on two levels: 1) internal or structural; 2) and external or strategic.

\section{IV. c. Structural Phases of Negotiation in Conflict Talk: \\ IV. c. 1. Initiating Conflict Talk:}

Negotiation is a dynamic process that happens when two interlocutors have different goals in the "selling-buying" model of communication (Maier, 2001). Rehbein (1995: 82) defines negotiation as "an auxiliary device, basically applied to different positions in different patterns". Negotiations occur when interlocutors argue to gain interests and benefits 
from each other. A conflict is an act that entails the presence of two participants at least to negotiate and start it.

In their attempt to show how a conflict is initiated, linguists proposed some verbal actions that can trigger opposition sequences. Eisenberg and Gravey (1981: 150) state that an argumentative "adversative episode is a sequence which begins with an opposition". Maynard (1985a) points out that an oppositional move, called "an antecedent event", must precede this adversative episode. Cortini (2001: 171) call it a "conflict antecedent". Pomerantz (1984a) offers an illuminating work on initial disagreement with an assessment based on the conversation analysis concept of "preference". She argues that in conversations, the preferred second pair part of the adjacency pair is the agreement. In other words, disagreements are considered dispreferred, in response to first pair parts of requests or invitations. Participants exert more effort and spend more time to produce dispreferred second turns. They resort to strategies such as delays, hesitations, justifications, explanations, partial repeats, and silence (ibid: 70). Following the same thread of thought, Boggs (1978) works on aggravated disagreement and introduces the term "contradicting routine". He states that in children's disputes, the most common unit of a contradicting argument is "no". It indicates direct disagreement.

Krainer (1988) follows the same line and includes all the negative lexical affixes as well. She calls them "strong challenges". Heritage (2002: 1432) adds the negative interrogatives to them. Goodwin (1990: 144) maintains that in children's conflict talk, opposition is sparkled through repetition of the previous utterance in addition to the use of the polar negators, "no" and "yes", to sustain disagreement, conflict, and challenge.

Also, Georgakopoulou (2001) pinpoints the importance of the rhetorical strategies of disagreement. They are the discourse "markers" that signify the beginning of the turn such as "but", "now", "well" and repeated questions.

Questions can restrict the contribution of the interlocutor's answer and consequently index an expected conflict (Harris, 1984; Drew and Heritage, 1992). Scott (2002: 317) states that questions may perform challenging functions in discourse: Impersonal or personal. An impersonal challenge is targeted at the addressee's point of view or proof. For example: "How do they know that?" Here, the challenge is directed towards the addressee's proof. On the other hand, a personal challenge is known as "an attempt to discredit the integrity of the interlocutor and thereby his argument" (ibid). For example: "Where were you then, Bill Press?" Here, the speaker's 
challenge is targeted at the rectitude and honesty of the interlocutor. This appears clearly by using the time adverbial, "then", that carries the pragmatic presupposition that he was absent by that time. The challenge is an accusation of negligence.

Sometimes, speakers do not offer accurate and appropriate answers to the questions given to them. They do this on purpose. They "side-step" (Clayman, 1993) the questions and topics offered to them in the previous question. This process is called "uptake avoidance" (Scott, 2002: 308). Other linguists discussed it but labeled it differently. Ochs (1979) called it "lack of uptake". Pomerantz (1984) named it "nonsense". And Galasinski $(2000,1996)$ identified it as "evasion". Consider the following example:

"Crossfire, 'The immigration debate, 7 July 1996'

BB: Where did they get the five million from?

DS: Well, first of all, the lady in the harbor has a book in her left

hand.The rule of law is what matters here" (In Scott, 2002: 309)

Here, BB's question is about the money they get from illegal immigration. However, the answer has no relationship to the question. DS's answer avoids the main question. His answer is about 'the rule of law' and he supports it with the adverb 'here'. Consequently, DS changes the focus of the question. This lack of uptake, if followed by BB, escalates the conflict in a new direction different from the first one. But if it is neglected, the conflict can be terminated.

\section{IV. c. 2. Escalating Conflict Talk:}

According to the adaptation theory, once conflict talk is initiated, it follows one of two trajectories of adaptation: escalation or termination. It is like a zigzag in which each move pertains to a counter move. Kotthoff (1993: 203) states that "when the context of argumentation is established, it is no longer preferred to agree. On the contrary, it seems very important to contradict quickly and in a coherent manner". The escalation of a conflict can be achieved through a multiplicity of variant language choices: 1) changing the focal point of the conflict; 2) substitution through cleft clauses; 3 ) format tying through cycled positions; 4) and irony.

\section{IV. c. 2. a. Changing the Focal point of the Conflict:}

Sometimes, the "focus" of the conflict is widened and expanded, by introducing other issues or topics, to disperse the attention of the interlocutors from the main cause of the conflict and forget it. Changing the focus during argumentation towards justifications or accounts is a negotiating process that escalates conflict talk (Boggs, 1978). In his attempt to change the focal point of the conflict, the speaker consciously chooses to 
cross the boundaries that are put to him by the other participant. In return, the hearer adapts his response and changes it from friendly to offensive. Look at the following example. It is a conversation between two participants about a project that is not performed.

"Qian Fanxing (Mayor): My dear monitor, please put it clearly:

what does our Big Boss ((a nickname for their superior,

Sectary Provincial CPC committee)) mean? Do we only

work on the project of Immigration and abandon the

project of Time Avenue? I've discussed the project of Time

Avenue with our Big Boss, and he showed support for this project.

Li Dongfang (Sectary of the municipal CPC committee):

Our Big Boss is still supportive of the project, but he asks us not to bite off more than we can chew. He showed reservations on this project compared with before!

Qian Fanxing: ((Looking at Li with discontent and saying ironically))

$\rightarrow$ Sectary Li, I do admire you! As soon as our Big Boss changed

his attitude, you changed yours too. You are such an expert in keeping pace with the superiors and I do believe there is still much room for you to improve.

\section{Li Dongfang:}

((flaring up)) Comrade Fanxing, how could you speak in this way? In what way I did change? When on earth did I ask you to make the project of Time Avenue such a big one?

Didn't you report to me until today? To say the least, even though I supported you before, now I want to accept the correct criticism and well-meant warning of Sectary Zhong.

Am I wrong on doing so?

\section{Qian Fanxing:}

((forcing a smiling face.)) Sectary Li, please don't take offence whatsoever. I was just kidding." (In Xiyuan, 2018: 121)

Here, instead of talking about the project of Time Avenue, the speakers adapt their behaviors to their psychological and social worlds and change the topic which is the main cause of discussion. Qian is unable to criticize the Big Boss because he is socially superior to him and to Li. So, he adapts his linguistic choice towards the process of changing the focal point. $\mathrm{He}$ directs his anger towards $\mathrm{Li}$, the Boss's secretary. Li interprets Qian's utterances as an offence. In turn, $\mathrm{Li}$ adapts his behaviors to the offensive 
one. The accounts which are offered by Li make Qian escalate the conflict towards another topic, Li's change.

\section{IV. c. 2. b. 1. Substitution through Cleft Clauses:}

The aggravation of opposition through "substitution" escalates conflict talk (van Leeuween and Wodak, 1999). Substitution is a change of the word order of the utterance, from the rheme to the theme, in order to index a specific element in it. Cleft clauses play a major role in achieving substitution in discourse. Speakers manipulate cleft clauses in particular instances to substitute the focal point of argument for another. They behave likewise for pragmatic reasons.

Oberland and Delin (1996: 188) point out that "the cleft clause, on the other hand, has been suggested to contain information that is rhematic and which therefore may contain new information". Halliday $(1967,1982,1985$ : 38) makes a distinction between the "thematic structure" and the "information structure" of the same sentence. For him, the theme is defined as "the communicative point of departure" of the message. The theme mostly occurs in the beginning of the sentence whereas the rheme occurs in the end of it. The information structure helps identify the type of information as "new" or "given". Generally speaking, new information or (rhematicity) tends to come in final positions in clauses. "A given utterance has to communicate something new or a new aspect of the established theme in order to contribute to the development of the discourse" (Liedtke, 2001: 240). Given information or (thematicity) occurs in initial position to sustain cohesion with previous sentences. "The strength with which some utterance is tied up with the preceding utterances in a certain conversational setting" (ibid). This means that old information will usually appear in a theme position rather than a rheme one. However, for pragmatic reasons, in the case of cleft clauses, speakers organize their utterances in ways that help them change the position of the focal point (or theme) of the sentence.

Although a cleft construction is similar in meaning to an active sentence, it is different in pragmatic terms. It is unique because while it marks one feature of the message, it presupposes another. A cleft sentence has three forms: 1) it- cleft (also called cleft, or "predicated theme" construction), 2) wh-cleft or "pseudo-cleft", and 3) reverse wh-cleft or "inverted pseudo-cleft" or reversed pseudo-cleft". Consider the following example:

"An active sentence: Arlette added the milk."

1.It-cleft: It was Arlette who added the milk.

It was the milk that Arlette added. 
2. Wh-cleft: the one] who added the milk was Arlette.

What Arlette added was the milk.

3. Reverse wh-cleft: Arlette was the one who added the milk.

The milk was what Arlette added." (Delin, 2000: 173) These sentences share the copula "be" and are either followed or preceded by the wh-cleft clause. Sentence (1), for instance, has the following structure: cleft pronoun "it" + copula "was" + clefted constituent "Arlette"+ cleft clause "who added the milk". In these sentences, cleft structures offer different pragmatic interpretations for the same active sentence. The sentences contain one presupposition and two assertions. The presupposition is "Someone added something." The first assertion focuses on the subject, "Arlette", as the one who added the milk, not anyone else. The second assertion focuses on the object, "the milk", not sugar or water for instance, as the added thing. Turning to 'wh-clefts', the focus or new information comes at the end of the sentence and the given part comes at the beginning of it.

Reverse wh-clefts are recognized as "fused" or "headless" when they include a "demonstrative", in initial position, followed by the copular "be" plus a "relativizer", e. g. what, when, why, etc. (Ball, 1991). Examples:

1. "I mean my idea would be to teach language and hire somebody to do the literature sort of thing you see

whereas if Roy Peel went, I suppose he'd do the literature and hire somebody to do the language

$\rightarrow$ That's what it would amount to isn't it"

2."So we ended up by saying end of September twentieth of September

$\rightarrow$ and that's when it's going to be". (Oberlander and Delin, 1996: 186)

\section{IV. c. 2. b. 2. Discourse Functions of Cleft Structures:}

It is up to the language user to select the form of the cleft structure that serves his pragmatic purposes. Both it-clefts and wh-clefts can function as discourse openers (Declerck, 1984: 258). She elaborates that when they do so, they belong to the "informative- presupposition" form. On the other hand, it-clefts and wh-clefts can also be used to focus stress on a specific element. It-clefts are always "specificational" whereas wh-clefts may be either "specificational or predicational" (Declerck, 2011: 69). She maintains that predicational constructions, "instead of specifying a value for a variable, (i.e., identifying a referent) they merely predicate something of the referent of the subject NP. In most cases, this 'something' is a characteristic, a role, a function, or an indication of class membership" (ibid: 57). Therefore, they are called to perform a function that is similar to stress and 
intonation in spoken discourse. It- clefts help discourse to proceed forward (Oberlander and Delin, 1997: 188). Declerck (1984: 273) states that whclefts suggest "interest and involvement" of the hearer towards what is uttered by the speakers. Some linguists point at the "summative" function in discourse of the reverse wh-cleft (Collins, 1991: 145; Stubbs, 1983). Others speak about the same function but label it "closing" (Oberlander and Delin, 1997: 188). This conforms to Weinert and Miller (1996: 191) who consider reverse wh-clefts structures that "gather up previous discourse". Collins (1991: 145) states that the reverse wh-cleft structure "pulls the threads of the discourse together", as it does not offer new information.

\section{IV. c. 2. c. Format Tying through Cycled Positions:}

Format tying is a salient structural process of adaptation during conflict talk. It maintains and escalates opposition by linking one part of the turn to a previous one. It can occur on the phonological, syntactic, and semantic level (Goodwin, 1990: 177). It is a process through which each participant recycles positions of opposition with the other one. Consider the following example:

"((Jonah is in his bedroom $))$

Mom: Jonah Lyle sweetie!

Something to do.

You have a project! ((Yelling from the kitchen $))$

Jonah: I'm not (.) doing it.

Mom: Yes you are:. $(($ singsong $))$

Jonah: No I'm no:t. ((singsong))

Mom: Oh Yes you are: ((singsong $))$

Jonah: Oh no I'm no:t.

Mom: If I have to drag you by the hairs of your chinny chin chin

((singsong $)$ )

Jonah: No I'm not.

Mom: ((walks towards Jonah's bedroom))

Oh yes I am. ((singsong))

Oh yes you are:." (Goodwin, 2006: 522)

In this example, Mom wants her son to wash his dishes. But he refuses by producing the polar "no". Mom does not give up. In response to him, she produces another polar item "yes". She insists on yelling at him. At the same time, Jonah insists on disobeying his Mom. In so doing, both Mom and Jonah recycle positions while repeating parts of the previous utterances. This process of recycled positions during opposition disputes is called format tying. The use of format tying links an utterance in a move to another 
utterance in the next move by repeating it. Hence, format tying maintains and escalates conflict talk.

\section{IV.c. 2. d. Irony:}

Irony and conflict talk are closely related. Leech (1991: 82) defines irony as "an apparently friendly way of being offensive". This also conforms to Sperber and Wilson (1981: 314) and Brown (1990: 123). For Ghita (2001: 139), irony is "socially dysfunctional". It makes the hearer feel uncomfortable and insecure. Irony is the outcome of the duality between what said and what is really meant. This pragmatic gap, between the semantic literal meaning and the intended meaning, creates irony. In confrontational interaction, the offensive intentions of the speakers are hidden behind their nice utterances. Consider this example between a husband, "A", and his wife, "B":

"A: That dress is really nice!

B: Will you stop teasing me all the time?" (Ghita, 2001: 146)

In this example, A's utterance looks like a compliment, on the surface. However, B knows that he does not really like her dress at all because he always criticizes her that she cannot select nice clothes that suit her shape. Therefore, she interprets his utterance from a pragmatic point of view as irony. Irony is based on the duality between the amicability that appears on the surface between the participants and the hostility that resides underneath. It reflects the contrast between the literal meaning, semantic, and the intended hidden meaning, pragmatic one. It is up to the addressee or "victim" (Dews, et al., 1995: 347-348) to pass it or to object to it by expressing disagreement. The victim adapts his behavior to the nonlinguistic context, namely, the psychological world. He escalates the covert conflict and turns it into an overt one.

\section{IV. d. Resolution and Termination of Conflict Talk:}

In the light of adaptation theory, once a conflict is established, interlocutors have a variety of dynamic options, to choose from, to resolve it: the "non-settlement approach", "the non-verbal approach", "the verbal approaches to settlement" (Fraser, 2001: 20), and the mediation.

In the non-settlement approach, one of the conflicting parties accepts what is offered to him by the other party. Or he postpones the conflict till it dies or loses its heat with the passage of time. Or he just walks out and disappears from the scene to avoid direct confrontation. Dersley and Wootton (2001: 613) call this walkout a "withdrawal format". For them, a withdrawal format does not mean that a conflict has gone to an end. Rather, 
"it sets up an expectation that, on next occasion, the nature of the division will need to be readdressed" (ibid).

In the non-verbal approach, one party exercises psychological harassment over the other party by giving him silent treatment to subjugate this objecting party to his desires. In the verbal approaches to settlement, the parties use verbal interaction to solve the conflict. They manipulate "keying" or "framing" (Hymes, 1974; Goffman, 1974) in a way that serves either to terminate or escalate the conflict during their interaction. They break the frame of the argument by disconnecting the turn from the previous one or by changing the topic. Sometimes, one party follows a tactic called "the guilt trip" where he showers the other party's head with heaps of utterances of guilt and shame. Thus, the other party prefers to give in and resolve the conflict rather than listen to more verbal aggression. The point here is that the three approaches to settlement, "non-settlement, non-verbal and verbal", involve the two conflicting parties only. But, by turning to the fourth approach, "mediation", we find a third party who is called "the mediator".

Mediation is "a form of negotiation, where two or more disputing parties engage in negotiation with the presence of a neutral third party" (Fraser, 2001: 23). This means that the mediator must adapt his linguistic contributions with the psychological and social worlds of the disputing couples. Mediation exists in the life of all of us. In divorce conflicts, mediation sessions play a very important role in de-escalating conflicts. Mediators help terminate conflicts through a variety of strategies: asking for clarification, changing topics, and negatively scolding the participants (Greatbatch and Dingwall, 1997). Consider this example:

"Mediator: People, you came in here to try to mediate a divorcesettlement rather than go to court for a trial which is scheduled tomorrow, with lawyers, witnesses and a drawn-out process. The whole nine yards. I let you vent at the outset, even tolerated some name-calling in an effort to let you get off steam before we got down to business. And we have made some limited progress.

But you have taken no constructive steps towards an agreement for the last two hours. You seem content to bicker, have me interrupt you, and in spite of my advice, begin to bickering again. Even when I caucused separately with you, I heard nothing but vituperation. So here's what I'm going to do. We're going to start with custody issue and we're going to discuss the interests of you, 
Martha, and those of you, Harry. And if I hear any comments offtopic, any name- calling, any side remarks, the mediation is over.

And I will report to the judge tomorrow morning before the trial why there was so little progress." (Fraser, 2001: 30)

In this mediation session, the mediator gives up his being neutral and adopts a coercive approach to resolve the conflict and de-escalate it before reaching the court. In his attempt to scold and threaten the couples, the mediator lists some of the linguistic strategies of conflict talk, e.g., namecalling, interruption, off-topic comments, and side remarks.

\section{Linguistic Strategies of Conflict Talk:}

People involved in conflict talk adapt their language choices to keep the balance between the context and the structure of their communication. In so doing, they select some linguistic strategies that index their anger and disagreement during negotiations. Researchers have identified the following devices as linguistic strategies of conflict talk: the direct address, absolutes and emphatics, floor bids and flow, bold statements and negative terms, and conditional threats.

The "direct address" of the disputing parties to each other reflects their anger (Gracia, 1991). Other linguists (Biber, 1988; Conner-Linton, 1989) add indexical second person pronouns, e.g., you, your and yourself. These pronouns mark the accusative tension between the disputing speakers.

"Absolutes" and "emphatics" index disagreement in discourse (Biber, 1988; Biber and Finegan, 1989). The following are examples of absolutes: all, anybody, nobody, etc. Examples of emphatics are 'a lot', 'at all', 'real'+ an adjective, etc. "Floor bid" and "flow" (Scott, 2002: 307) are other linguistic devices used to index struggle and disagreement in conflict talk.

As its name suggests, "floor bid" stands for an utterance which is used to prevent other speakers from talking and holding the floor. For example: "let me talk"; "just a minute". On the other hand, "flow" stands for the integration of "overlapping" and "latching". Overlapping occurs when two speakers talk simultaneously. It reflects a feeling of disorder, trouble, and struggle. Latching occurs when a new participant immediately talks after the utterance of the previous speaker, without any perceptible pauses between the different turns by the different speakers.

"Bold statements" and "negative terms" (Rees- Miller, 2000: 1094) are additional linguistic devices that reflect conflict talk and escalate it. Instead of challenging each other indirectly by resorting to questions, the participants manipulate direct bold statements that include negative labels to display their anger and conflict. Klerk (1997: 147) handles "negative terms" 
but labels them "expletives". Infante and Rancer (1996) call them "verbal aggressiveness".

Pragmatically speaking, conditional threats are used to affect the hearer's decisions. They reflect the strategic comment of the speaker towards his utterance. Speakers challenge each other via the use of conditional threats which in turn restrict the hearer's behaviors. Linguists differentiate between conditional threats and promises. Nickerson (2015: 91) states that "both are intended to affect behavior, promises with positive inducements, and threats with negative ones". Conditional threats are used disjunctively and conjunctively whereas conditional promises are used conjunctively only. Consider the following examples:

1."If you do..., I'll do..." $\rightarrow$ (a promise and a threat) (Rooij and Franke, 2010:1)

2."Do X and I will reward you; do Y and I will punish you." (Nickerson, 2015: 91)

3. "You do..., or I'll do..." $\rightarrow$ (a threat only) (Rooij and Franke, 2010:1)

4. "Refrain from doing Y or I will punish you". (Nickerson, 2015: 91)

Here, examples (1) and (2) can be interpreted as conditional promises and threats. This is due to the implicit or explicit use of the coordinating conjunction 'and'. On the other hand, examples (3) and (4) are interpreted only as conditional threats because of the use of the disjunction 'or'.

\section{Theoretical Framework:}

This research paper studies conflict talk in Noah Baumbach's Marriage Story. It offers an interdisciplinary study of the challenging negotiations of divorce between the lead characters, Charlie and Nicole, and the lawyers who represent them in court, namely, Bert, Jay, and Nora. The analysis is hand-made by the researcher. It focuses mainly on the conversations between these characters. The paper attempts to identify the main causes of conflict talk and to change people's behavior towards them. The study is interdisciplinary as it derives from conversation analysis, discourse analysis and pragmatics. As for conversation analysis, it analyses conversations that take place in naturally occurring situations between participants involved in divorce negotiations. In so doing, the researcher offers a transcription of conversations according to Jefferson's model (1981). Concerning discourse analysis, it deals with the utterances of the speakers as a process of linguistic interaction in which each speaker makes the link between what is said, what is done and what is even not said or 
done. The speaker is busy all the time filling in the gaps in conflict discourse. In his attempt to search for the appropriate utterances, the conflicting party must be alert to what he is saying otherwise he will be a loser. He hides his intentions to look friendly even though he is not likewise. And this is where pragmatics works.

This paper applies Verschueren's pragmatic model of Adaptation to variables. It studies the triangular relationship between variability, negotiability, and adaptability. It claims that language use is a matter of permanent choice from the variables in the language. In this sense, conflict talk is a linguistic choice where the participants adapt disputing behaviors during their dynamic negotiations to realize their needs. The paper focuses mainly on the contextual correlates of adaptability with respect to variables in the psychological, social, and physical world. In the light of adaptation theory, the paper offers a theoretical framework that deals with conflict talk from two facets: structural and strategic. Structurally speaking, it presents three different phases of conflict talk: initiation, escalation, and termination. It is difficult to separate the three phases from each other because they are entangled in most of the cases. However, the researcher will do his best. Concerning the initiation of conflict talk, the research focuses on the 'conflict antecedent'. Relating to the escalation of conflict talk, the research pinpoints the following ways: 1) changing the focal point of the conflict; 2) substitution through cleft clauses; 3) format tying through cycled positions; 4) and irony. As for the termination of conflict talk, the research highlights the role of the 'mediation'. The strategic part of conflict talk always accompanies the structural part. It offers a matrix of the linguistic strategies that work as makeups for the conflict and enhance its heat. The research focuses on the following linguistic strategies: 1) direct address and indexical second person pronouns; 2) bold statements and expletives; 3) and negation.

\section{Transcription Notation:}

\begin{tabular}{|l|l|}
\hline$()$. & indicates a short pause. \\
\hline[] & refer to overlapping speech. \\
\hline$=$ & $\begin{array}{l}\text { marks latching of successive speech of one or more speakers immediately with } \\
\text { no pauses in between. }\end{array}$ \\
\hline$(())$ & refer to non- verbal action that is not included in speech. \\
\hline Underlining & reflects emphasis in speech on a specific thing. \\
\hline Capitalization & marks loudness of speech or screaming. \\
\hline$:$ & Indicates prolongation of the vowel. \\
\hline$--->$ & Points at relevant items. \\
\hline
\end{tabular}




\section{Analysis of Data:}

VII. a. The Structural Phases of Negotiation in Conflict Talk:

\section{VII. a. 1. Initiation of Conflict Talk:}

Baumbach's Marriage Story is replete with many instances of conflict talk. In their negotiations together on divorce, the spouses introduce a 'conflict antecedent' that initiates their conflict talk. It always triggers a series of opposing sequences. According to adaptation theory, the conflict antecedent invokes a conflicting response between the participants. Here, the addresser thinks that the addressee has done something wrong. The conflict antecedent results from the lack of adaptability between the speakers. Consider the following example. It is between Charlie and Nicole. Charlie is shocked by Nora's telephone call about Nicole's financial rights and custody. The physical context is Nicole's house in Los Angeles.

"Charlie: I got a call from your lawyer (.) She said you'd take everything and custody and everything if I didn't respond (.)

Nicole: That's how lawyers talk (.)

$\rightarrow$ Charlie: Yeah, but she's saying things I don't think you mean (.)

Nicole: It's better if we just let the lawyers do this (.)

Charlie: We said we'd figure this out together (.)

Nicole: Have you gotten a lawyer yet?

Charlie: That's what I'm here to do (.) And I looked Nora up (.)

She's fancy (.) We ... you can't afford her (.)

Nicole: She said she'd make it work (.)" (Baumbach, 2019: 67)

Here, Charlie and Nicole do not chare the same frame of communication. They adapt different frames. Charlie starts his negotiation from a fact- based frame as he says: 'I got a call from your lawyer'. He is concerned with the message that Nora delivers to him. On the other hand, Nicole adapts a value frame as she comments on the manner of her lawyer's talk. Perceiving the variance in Nicole's frame, he uses the conflict antecedent, 'but she's saying things I don't think you mean', preceded by 'but' to help her adapt her response to his frame. Unfortunately, Nicole sticks to her psychological world. The conflict arises in this point because they are psychologically detached from each other. Each one is in his separate mental world. So, their adaptation is divergent. Charlie is astonished at his wife's cold reaction. She chooses to do everything through her lawyer. When they were living together, they were having the same frame. Charlie appeals to the interest frame as he reminds her with their previous deals. But now, things became different. Nicole broke her previous promise with him that they will figure things out without lawyers. Consequently, Charlie 
finds himself obliged to hire a lawyer to protect himself from her. This triggers a series of hot conflicts and hard negotiations.

The following table represents different instances of 'conflict antecedents' that initiate many discourse disputes between the interlocutors.

Table (1)

Initiating Conflict Talk

\begin{tabular}{|l|l|l|}
\hline Language Users & Conflict Antecedents & Page Number \\
\hline $\begin{array}{l}\text { Charlie VS Nicole } \\
\text { Charlie VS Nora }\end{array}$ & $\begin{array}{l}\text { But I don't want THIS (.) } \\
\text { But I thought that's just what it says } \\
\text { (.) ... we weren't going to even do it } \\
\text { with lawyers (.) } \\
\text { Yeah, but she's saying things I don't } \\
\text { think you mean (.) } \\
\text { My lawyers wouldn't let me sign } \\
\text { anything (.) }\end{array}$ & 63 \\
Bert VS Nora & $\begin{array}{l}\text { Nora, you seem to be ignoring the } \\
\text { fact that they LIVED in New York } \\
\text { for ten years (-) }\end{array}$ & 91 \\
Bert VS Nora & $\begin{array}{l}\text {..But all our personal feelings about } \\
\text { the two cities aside, we DON'T share } \\
\text { your assertion that the couple is an } \\
\text { LA based family(.) } \\
\text { My client will NO::T be slut-shamed } \\
\text { for an artistic choice (.) }\end{array}$ & 108 \\
Charlie VS Nicole & $\begin{array}{l}\text { But could you change it so I can take } \\
\text { him? } \\
\text { Well, that's not (.) Charlie, that's not } \\
\text { a useful way for us to start (.) }\end{array}$ & 114 \\
Nicole VS Charlie & instances Of conflict antecedents \\
\hline
\end{tabular}

Most of these instances of conflict antecedents are preceded by the discourse marker "but" that sets the interlocutor on the mood of opposition. The other instances include the negative "not" to sustain disagreement and challenge. They all reflect problems in adaptation between the conflicting persons during communication. No one is ready to adapt his behavior to conform to the needs of hid partner. They always choose to be different. They refuse change. Once conflict talk is initiated and not resolved, it goes forward towards escalation which is the next stage of the discourse of conflict.

VII. a. 2. Escalating Conflict Talk:

VII. a. 2. a. Changing the Focal Point of the Conflict: 
Being involved in conflict talk, the participants choose to neglect the main topic of talk and change it. In their attempts to launch their attack on each other, they drift towards other topics that do not belong to the original topic. They negotiate from two different cognitive perspectives. They do not direct negotiating process towards the same mental way of thinking. Look at the following example. It is between Charlie and Nicole. The main topic is 'why Nicole wants to stay in LA?' Unfortunately, the discourse does not proceed on this topic. It changes the focal point to be 'Charlie's fuck of Mary Ann', the woman who works with them in their theater. The physical world is Nicole's house in Los Angeles.

"Nicole: You don't remember promising that we could do time out here?

Charlie: We discussed things (.) We talked about moving to Europe, about getting a sideboard or what you call it, a credenza, to fill that empty space behind the couch (.) We never did any of it (.)

Nicole: And you turned down that residency at the Geffen that would have brought us here and [

Charlie: [It wasn't something I wanted (.) We had a great theater company and a great life where we were (.)

Nicole: You call that a great life?

Charlie: You know what I mean (.)

$\rightarrow$ Nicole: Me discovering you're FUCKING Mary Ann (.)

Charlie: Don't pretend you're not capable of deception (.) You LEFT Ben

For ME (.)" (Ibid: 117)

Here, Charlie interprets Nicole's first interrogative as an indirect accusation of being deceptive. To mitigate this feeling and adapt to the conventions of the social world that evaluate the non- fulfillment of promises negatively, he responds by selecting the word 'discuss' rather than 'promise'. Realizing that he is alluding from her, Nicole adapts her language use towards directness of speech. She selects a direct bold statement to index her accusation. Charlie responds to her according to his psychological perspective. He says: 'It wasn't something I wanted.' So, we perceive that the conflict between them is psychological. Each one clings to his wants. No one wants to adapt his needs to the needs of his partner. Again, Nicole selects another direct bold statement, 'Me discovering you're FUCKING Mary Ann', and changes the focal point of interaction. There is no relationship at all between Nicole's wish to live in LA and Charlie's act of cheating on her. In response to her, Charlie adapts his reaction from being defensive into being offensive. He escalates the conflict and accuses her of being deceptive exactly like him. The point here is that conflict talk is like a 
thread of yarn that unfolds itself with the passage of time. The more the interlocutors talk to get off steam, the more they change the focal point of the conflict and the more they become more challenging during their negotiations. In one of their fights, Charlie perceived this fact. He said to Nicole: "I think you're conflating two different things (.) Mary Ann has NOTHING to do with LA (.)" (Ibid: 92)

The following table sums up the situations of conflict talk between the interlocutors that get escalated through the change of the focal point of the conflict.

Table (2)

Changing the Focal Point of the Conflict

\begin{tabular}{|c|c|c|}
\hline $\begin{array}{l}\text { Language } \\
\text { Users }\end{array}$ & Changing the Focal Point of the Conflict & $\begin{array}{l}\text { Page } \\
\text { Number }\end{array}$ \\
\hline Jay & Does your wife's family have money? & 55 \\
\hline Charlie & HOW DID YOU READ MY EMAILS? & 92 \\
\hline Nora & $\begin{array}{l}\text { Charlie, can I ask you: How can you expect to have more time with } \\
\text { Henry when you don't exercise time you have AND exercise it }\end{array}$ & 111 \\
\hline Nicole & responsibly? & 117 \\
\hline Nicole & ME discovering you're FUCKING Mary Ann (.) & 119 \\
\hline Nicole & Nora says there's no coming back from this (.) & 120 \\
\hline Charlie & You're been so much like your father (.) & 122 \\
\hline Charlie & $\begin{array}{l}\text { Life with you was JOYLESS }(.) \\
\text { What does that have to do with LA? }\end{array}$ & 124 \\
\hline
\end{tabular}

As this table shows, the researcher finds that changing the focal point of the conflict is a major negotiating process of adaptability that the participants select to escalate their conflict talk. Jay Marotta, the second layer of Charlie, manipulates it to make Nicole's mother involved in the case. Jay wants to draw her leg simply to get more money from his clients. In contrast, Nora, Nicole's lawyer, uses the same processes to condemn Charlie and to make him appear as an irresponsible father in front of the judge. So, she manipulates it to win in the court. Turning to Charlie and Nicole, they manipulate this process to alternate accusative charges against each other. But none of the topics that they propose relates to the main topic, staying in LA.

\section{VII. a. 2. b. Substitution through Cleft Clauses:}

Substitution is another dynamic negotiation process that is used to escalate conflict talk between Charlie and Nicole in their divorce conflicts. They and their representative lawyers substitute the word order of the utterances to index certain elements in their oppositional arguments. In so 
doing, they manipulate three types of cleft clauses: it- cleft, wh- cleft and reverse wh-cleft.

It- clefts are used to achieve substitution of word order during divorce negotiations. Each speaker wants to support his own argument and to refute the other party's claim. Look at this example. It is between Bert, Charlie's first lawyer, and Nora. The physical world is the court.

" $\rightarrow$ Bert: It's my client's expectation that after this T.V. show is

completed, the parties will move back to New York where they currently keep an apartment $=$

$\rightarrow$ Nora: $=$ And it's my understanding that Charlie PROMISED Nicole that they will spend more time in LA during the marriage (.) but

because of Charlie's insistence that his work keep them in New

York, Nicole ended up staying much longer than she ever anticipated (.) In fact, a few years ago, Charlie was offered a residency at the Geffen Playhouse that would have taken his

work and family to LA for a year (.) and he turned it down knowing full well that this was Nicole's desire (.)" (Ibid: 95)

Here, Bert selects the 'it-cleft' structure to give an account for Charlie's sake. He manipulates the 'it-clause' to specify the noun phrase 'my client's expectation'. Thus, he shows that he is concerned about his client's interests and to show that Nicole's behavior does not conform to Charlie's psychological expectations. She deceived him and stole his son from him. Contrarily, Nora, manipulates the same process to specify the noun phrase 'my understanding' to counteract Bert's assumption. Nora wants to prove that Charlie did not fulfill his promise to Nicole to move to LA. Hence, the two lawyers use the same structure to specify the fact that Nicole and Charlie are psychologically disappointing to each other.

Wh-clefts are also used to achieve substitution of word order between the conflicting parties in Marriage Story. The physical world is Nora's office in Los Angeles. Consider the following example:

"Nicole: I just worry... (.) You know we weren't going to even use lawyers

friends (.)

so... (.) I don't want to be too aggressive (.) I'd like to stay

Nora : Don't worry, we'll do it as gently as possible (.) ((beat))

Now, can you tell me a little bit more about what's going on?

$\rightarrow$ Because part of what we're going to do together is tell your

STORY (.)" (ibid: 33) 
Selecting to use the wh-cleft structure, Nora becomes able to decide part of the role that she will play with Nicole. They are going to tell Nicole's STORY. So, Nora's new information comes at the end of the clause. Nora, bearing in mind that Nicole and Charlie agreed together that they will be separated easily with no lawyers, uses the wh- cleft structure to convince Nicole to proceed forward against Charlie. Nora says to Nicole: "what you're doing is an act of HOPE (.) Do you understand that?" (ibid: 32). Nora wants to win Nicole's case. So, she adapts her thinking towards Nicole's psychological world that is sinking in despair at the current time. She psychologically supports Nicole by telling her that she is in the right track. Nora gives Nicole hope for a better future.

Another type of cleft clauses that is used to achieve substitution of word order is the 'reverse wh-clefts'. Consider this example of 'reverse whclefts'. It is an extract from the conversation between Nora and Charlie on the phone. Nora calls Charlie to warn him that if he does not file his response to her within a month, which is already about to pass, she will file a request for default judgment against him. The physical world is Charlie's theatre in New York.

"Nora: We'll be able to lay claim to whatever we want (.)

Charlie: What do you mean? Whatever you want of what?

Nora: Your apartment, your things (.) well, everything you own (.)

Charlie: She and I already discussed this, we don't own that much stuff, she can have pretty much whatever she [

Nora:[ And it means, we'll set the number for child support at the

highest level and claim full custody of your child...=

Charlie: $(($ alarmed $))=$ Full custody? I mean that's no::t even..

$\rightarrow$ Nora: This is what the law says (.)

Charlie: Nicole's not going to do that. I mean (.) she won't =

Nora: = No:, Charlie, I represent Nicole and she's aware of everything I'm

saying to you (.)" (Ibid: 65)

Here, Charlie is alarmed by Nicole's behavior. He never expects that she or her lawyer can behave likewise. However, Nora, in her response to him, uses the reverse wh-cleft to school him the rules of law. Choosing the reverse wh-cleft, Nora adapts her utterance to the factual frame of interaction that puts Charlie psychologically in a lower social status than her and Nicole, her client. This emphasizes her power as a representative of law. The demonstrative 'this' followed by the copula 'is' and the 'what clause' postpone the new information till the end of the sentence. Thus, Nora 
succeeds in justifying whatever she is doing to Charlie by relating it to the social world and law.

The following table offers a summary of substitution through the use of cleft clauses.

Table (3)

Substitution through Cleft Clauses

\begin{tabular}{|c|c|c|c|}
\hline $\begin{array}{l}\text { Type of Cleft } \\
\text { Clause }\end{array}$ & $\begin{array}{l}\text { Language } \\
\text { Users }\end{array}$ & Utterances & $\begin{array}{l}\text { Page } \\
\text { Number }\end{array}$ \\
\hline \multirow[t]{7}{*}{ It- Clefts } & Bert & It's just how we have to think about it (.) & 77 \\
\hline & Bert & It's my client's expectation that after this T.V. show is & 95 \\
\hline & Bert & It was very clearly their deal that they would go back to New & 98 \\
\hline & Nora & $\begin{array}{l}\text { And it's my understanding that Charlie PROMISED Nicole that } \\
\text { they will spend more time in LA (.) }\end{array}$ & 95 \\
\hline & Nora & $\begin{array}{l}\text { It's a deal when it's something you want, but it's a discussion } \\
\text { when Nicole wants it? }\end{array}$ & 9 \\
\hline & Charlie & It's what you want to HEAR (.) & 120 \\
\hline & Charlie & It wasn't something I wanted (.) & 117 \\
\hline Wh-Clefts & $\begin{array}{l}\text { Nora } \\
\text { Nora }\end{array}$ & $\begin{array}{l}\text { What you're doing is an act of HOPE (.) } \\
\text { What we're going to do together is tell your STORY (.) }\end{array}$ & $\begin{array}{ll}32 \\
33\end{array}$ \\
\hline \multirow{14}{*}{$\begin{array}{l}\text { Reverse } \\
\text { Clefts }\end{array}$} & Nicole & That's when I realized that he truly didn't see me (.) & 36 \\
\hline & Nicole & That's how lawyers talk (.) & 67 \\
\hline & Jay & This is what I would suggest, you take the kid (.) to New York & 54 \\
\hline & Jay & That's something people say when they win awards & \\
\hline & Charlie & That's just what it says (-) & 109 \\
\hline & Charlie & That's what I'm here to do (.) & 63 \\
\hline & & & 68 \\
\hline & Charlie & That's where we live ((means New York $))$ & 132 \\
\hline & Nora & This is what the law says (.) & 65 \\
\hline & Nora & That's what all that honking is! & 66 \\
\hline & Bert & That's why I graduated into family law (.) & 00 \\
\hline & $\begin{array}{l}\text { Bert } \\
\text { Bert }\end{array}$ & $\begin{array}{l}\text { Here's how I see it }(.) \\
\text { The win is what's best for Henry (.) }\end{array}$ & $\begin{array}{l}77 \\
79\end{array}$ \\
\hline & & This is a person you had a great feeling for(.) & 100 \\
\hline & & & 10 \\
\hline
\end{tabular}

This table shows that substitution through the use of cleft clauses plays an important role in divorce negotiations. Cleft clauses are saliently selected to escalate conflict talk and to adapt it towards the users' mental and social perspectives of the world. Each participant manipulates them to support his own party in its conflict against the other part. The main target is to 'win' the war of custody, regardless of the price that will be paid. The only wise person who states this clearly is Bert, the old lawyer. Bert says: 
"the win is what is best for Henry" (ibid: 100). He chooses the reverse cleft clause to draw the attention of the conflicting parties to the real definition of 'win' as 'what is best for Henry', their son. Thus, he shows clearly that the win is not what Charlie or Nicole wants. Rather, it is their son's benefits. Bert wants to make Charlie and Nicole's adapt their inner thoughts towards their son. Unfortunately, they do not listen to Bert's advice and they got engaged in more conflict talk.

\section{VII. a. 2. c. Format Tying through cycled Positions:}

One of the dynamic negotiation processes that the conflicting parties use to escalate conflict talk in Marriage Story is format tying. During this process, they alternate opposition by repeating one part of the previous utterance or the whole of it. In so doing, they recycle positions of opposition. Look at the following example. The physical world is Charlie's rented house in Los Angeles.

"Nicole: Did you find a lawyer?

Charlie: Yes (.) Henry says you're moving here?

Nicole: Have your lawyer call Nora (.)

Charlie: I want to talk about it as us =

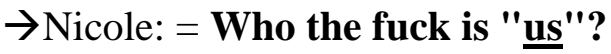

Charlie: Let's just get in a room, you and ME, that's what we always said We'd do (.)

$\rightarrow$ Nicole: My lawyers wouldn't let me sign anything (.)

$\rightarrow$ Charlie: It's not up to them (.) It's up to us (.) It's OUR divorce (.)

Nicole: They say I would later sue them for malpractice (.)

$\rightarrow$ Charlie: ((frustrated and angry)) What am I walking into?

$\rightarrow$ Nicole: $=$ What are you walking into?

$\rightarrow$ Charlie: $=$ Yes! What the fuck is going on?

$\rightarrow$ Nicole: I read your fucking emails, CHARLIE (.) I read them all (.)" (Ibid: 91)

In his attempt to resolve the conflict, Charlie asks Nicole to adapt her psychological world towards his by using the pronoun 'us' that indicates oneness and unity. He says to Nicole: 'I want to talk about it as us', but Nicole refuses to terminate it. Rather, her response escalates the conflict. Instead of conforming to him, she takes the turn immediately and asks: 'who the fuck is "us"?'. When he reminded her with what they said they 'would' do, she recycled the position by repeating the same modal, 'wouldn't', and negating it. Then, when he asked: 'what am I walking into', she repeated the whole question again and only changed the first- person pronoun 'I' into the indexical pronoun 'you'. She did not offer him an answer to his question. So, 
he produced the polar response 'yes' and then followed it with another question, 'what the fuck is going on?' In turn, Nicole answered him back by repeating the same modifier 'fucking' to modify his emails. So, the participants tie the end of one utterance to the beginning of the second utterance by the next speaker. Of course, they do this while following the lines of direct opposition. Therefore, conflict talk goes on a process of nonstop conflicts to the extent that they forget why they are fighting together from the very beginning. They are trapped in their repeated pattern of interaction. This is called format tying.

The following table sums up the situations of format tying using cycled positions in the movie.

\begin{tabular}{|c|c|c|}
\hline $\begin{array}{l}\text { Table(4):Format tying } \\
\text { throughCycled } \\
\text { Positions } \\
\text { Page Number }\end{array}$ & Format Tying & $\begin{array}{l}\text { Language } \\
\text { Users }\end{array}$ \\
\hline 70 & $\begin{array}{l}\text { I just spoke to her this morning (.) } \\
=\text { Well, I spoke to her five minutes before I got on this call (.) }\end{array}$ & $\begin{array}{l}\text { Charlie VS } \\
\text { Nor }\end{array}$ \\
\hline १) & $\begin{array}{l}\text { I want to talk about it as us. } \\
\text { =Who the fuck is "us" }\end{array}$ & $\begin{array}{l}\text { Charlie VS } \\
\text { Nicole }\end{array}$ \\
\hline 90 & $\begin{array}{l}\text { We want to maintain consistency for his family and his child (.) } \\
\text { =Was this the same consistency he wanted to maintain when they } \\
\text { went to Copenhagen for six months so he could direct a play? }\end{array}$ & $\begin{array}{l}\text { Bert VS } \\
\text { Nora }\end{array}$ \\
\hline 91 & $\begin{array}{l}\text { It was very clearly their deal that they would go back to New York } \\
\text { after Nicole finished her show (.) } \\
=\text { I'm not aware of any deal (.) } \\
((\text { can't help himself }))=\text { I didn't get it in writing }(.)\end{array}$ & $\begin{array}{l}\text { Bert VS } \\
\text { Nora VS } \\
\text { Charlie }\end{array}$ \\
\hline $1 \cdot 1$ & $\begin{array}{l}\text { She also supplied Charlie with a loan early on to help out (.) } \\
=\text { Which he paid back (.) }\end{array}$ & $\begin{array}{l}\text { Nora VS } \\
\text { Jay }\end{array}$ \\
\hline 1.9 & $\begin{array}{l}\text { I don't see how you can claim that she gets half a grant dedicated to } \\
\text { his genius. } \\
\text { =He became a genius during the course of the marriage (.) }\end{array}$ & $\begin{array}{l}\text { Jay VS } \\
\text { Nora }\end{array}$ \\
\hline 11. & $\begin{array}{l}\text { Nicole is withholding Henry, alienating him from his father (.) This } \\
\text { has turned Charlie's world upside down (.) It amounts to an ambush } \\
\text { (.) } \\
\text { =Withholding, Jay? Really? Alienating (.) Those are fighting words } \\
\text { and it is simply false and does nothing to further our settlement (.) } \\
\text { Your recap of this situation is outrageous (.) }\end{array}$ & $\begin{array}{l}\text { Jay VS } \\
\text { Nora }\end{array}$ \\
\hline $11 \leq$ & $\begin{array}{l}\text { I'm just asking you to be flexible (.) } \\
=\text { I AM flexible (.) You come in and out and I adjust based on your } \\
\text { schedule (.) }\end{array}$ & $\begin{array}{l}\text { Charlie VS } \\
\text { Nicole }\end{array}$ \\
\hline 111 & $\begin{array}{l}\text { We did say it (.) } \\
=\text { When did we say it? }\end{array}$ & $\begin{array}{l}\text { Charlie VS } \\
\text { Nicole }\end{array}$ \\
\hline ITr & $\begin{array}{l}\text { You USED me so you could get out of LA (.) } \\
=\text { I didn't use you (-) }\end{array}$ & $\begin{array}{l}\text { Charlie VS } \\
\text { Nicole }\end{array}$ \\
\hline Tri & $\begin{array}{l}\text { She didn't hate me (.) You hated me (.) } \\
=\text { You hated ME (.) You fucked someone we worked with (.) }\end{array}$ & $\begin{array}{l}\text { Charlie VS } \\
\text { Nicole }\end{array}$ \\
\hline
\end{tabular}

This table shows that format tying is an important negotiation process which escalates conflict talk. It helps the conflicting parties to cross talk each other. Consequently, they handle as much topics as possible. 
Latching between the turns increases the tension between the participants. The most important point here is that while they fight, they always recycle positions. They do not talk together anymore. Rather, they talk past each other. In this dynamic process of negotiation, one party produces a point whereas the other party produces its counterpoint.

\section{VII. a. 2. d. Irony:}

Irony is used in Marriage Story in a very hectic time. Charlie and Nicole's use of it escalates conflict talk to a point from which there is no coming back. It is used only once, in the big fight. In the light of adaptation theory, irony is a conscious language choice where language users produce an utterance whose literal meaning does not conform to its intended interpretation. The conflict results from the adaptability, and not the lack of adaptability, between the psychological and the social world. Look at the following extract. The physical world is Charlie's rented house in Los Angeles.

$" \rightarrow$ Nicole: You're being so much like your father (.)

Charlie: $=$ DO NOT compare me to my father (.)

Nicole: I did'nt compare you (.) I said you were acting like him (.)

Charlie: = You're exactly like your mother! Everything you complain about her, you're doing (.) You're suffocating Henry (.)

Nicole: First of all, I love my mother, she was a great mother (.)

Charlie: I'm repeating what you have told me (.)" (Ibid: 121)

Nicole's utterance, 'you're being so much like your father', is a friendly way of being offensive. Based on the famous example, 'like father like son', people like to be attributed to their parents. In general, this conforms to the conventions of the social world in which such an utterance is interpreted as a compliment. However, this is not the case in this communicative context. Charlie's adaptation to Nicole's psychological world makes him realize her bad intentions. He interprets it as an irony and becomes very angry. He perceives the pragmatic gap between the indirect nice utterance and its hidden intended bad meaning. Consequently, he develops his offensive behavior towards Nicole and showers her with expletives and direct declarative statements that bear many negative terms.

\section{VII. a. 3. Termination of Conflict Talk:}

\section{VII. a. 3. a. Mediation:}

Mediation is very important during divorce sessions. The mediator must be both neutral and coercive. He should not take any side of the conflicting parties. Nicole and Charlie seek a mediator to mediate their separation and divorce. Although he follows some procedures to fix things 
with them, he fails. He does not exert enough effort on divorce negotiations. He gives up being neutral. He starts by asking each one of them to write a note of positivity in which they mention "why they got married in the first place"(Ibid, 10). Charlie complies with the mediator's request. But Nicole does not. Consider the following extract. The physical world is at the mediator's office in New York.

" Charlie: I'll read mine (.) I like what I wrote (.)

Mediator: For it really work, you both have to read (-)

Nicole: ((folding up her paper)) I'm not going to read.

Mediator: Ok (.)

Charlie: She always says I can't write (.) But I think mine is pretty good (.)

Mediator: Nicole, maybe you'll change your mind once you hear Charlie's(.)

Nicole: ((looking at him now )) I don't want to hear Charlie (.)

Charlie: We promised to listen (.)

$\rightarrow$ Mediator: That's right, that's the very first step in this process (.)

((Nicole stands up, suddenly furious. ))

Nicole: I think I'll go if you two are just going to sit around and suck each other's dicks!" (ibid: 10-11)

Here, the mediator manipulates the following linguistic strategies: name calling, indexical pronouns, imperatives and reverse-cleft structure. He starts his mediation with them by explaining the plan that he is going to follow during their divorce session. He refers to them as 'people'; then he uses the indexical pronoun, 'you' and follows it by 'both' to refer to them. Lately, he specifies his talk to Nicole by the direct address of her name. But he made a great mistake on Nicole's behalf. He adapts his behavior, only, with Charlie's psychological world and neglects Nicole's. He asks her to behave in the same manner. Instead of asking her about the reason why she does not want to hear Charlie's, he takes Charlie's side and insists that she must follow his protocol. He forgets that each person represents a specific psychological case in need of care. He uses the reverse cleft structure, 'that's the very first step in this process', to support Charlie and focus on the first step that he decided for Nicole and Charlie to follow. He does not listen to her story. Consequently, Nicole gets furious, threatens the two of them, and finally uses negative terms to describe their behavior. Instead of resolving the conflict and terminating it through mediation, the mediator paves the way for lawyers to proceed forward in courts with their nominated clients.

VII. b. Linguistic Strategies of Conflict Talk:

VII. b. 1. Direct Address and Indexical Second Person Pronouns: 
During conflict talk, the negotiating parties select to use direct address in addition to indexical second person pronouns to vent their anger. In the divorce story of Charlie and Nicole, they and their lawyers use them many times to mark the accusative senses toward each other. Consider the following example. It is a part of the big fight between the spouses, Nicole and Charlie. The physical world is Charlie's new rented house in Los Angeles.

"Nicole: Do you understand why I want to stay in LA?

Charlie: No (.)

Nicole: Well, that's not (-) Charlie, that's not a useful way for us to start(.)

Charlie: I don't understand it (.)

You know what I mean (.)

Nicole: Me discovering you're fucking Mary Ann (-)

Charlie: $=$ Don't pretend you're not capable of deception (.) You left Ben for ME (.) I don't mean we had a great marriage (.) I mean life in Brooklyn (-) Professionally (.) I don't know (.) Honestly I never considered anything different (.)

Nicole: Well, that's the problem isn't it? I was your wife, you should have considered my happiness too (.)

Charlie: Come on! You WERE happy (.) You've just decided you weren't now (.)" (Ibid, 117)

The selection of direct address in addition to second person indexical pronouns increase the senses of accusation and offence during the conversation. Instead of talking together as a whole unit by using the pronoun "we", they alternate accusative charges to each other. Each one accuses the other partner of being in-adaptive to his/her psychological world. Nicole says to him: 'you should have considered my happiness'. Charlie responds: 'you WERE happy. You've just decided you weren't now'. Charlie reaches the conclusion that happiness is a conscious decision in the mind according to which she adapts her behavior to follow. Results of the negotiation processes between them turn from bad to worse because of their manipulation of indexical pronouns and the polar negation "no".

The following table presents the instances of the use of direct address and indexical second person pronouns. 
Table (5)

Direct Address and Indexical Second Person Pronouns

\begin{tabular}{|c|c|c|c|}
\hline $\begin{array}{l}\text { Linguistic } \\
\text { Strategies } \\
\end{array}$ & $\begin{array}{l}\text { Language } \\
\text { Users }\end{array}$ & Page Number & Frequency \\
\hline Direct Address & $\begin{array}{l}\text { Mediator } \\
\text { Nicole } \\
\text { Nora } \\
\text { Jay } \\
\text { Bert }\end{array}$ & $\begin{array}{l}10 \\
114,17 \\
65,110,111 \\
110,111 \\
94\end{array}$ & $\begin{array}{l}1 \\
2 \\
4 \\
3 \\
1\end{array}$ \\
\hline $\begin{array}{l}\text { Indexical } \\
\text { Pronouns }\end{array}$ & $\begin{array}{l}\text { Nicole } \\
\text { Charlie } \\
\text { Nora } \\
\text { Jay }\end{array}$ & $\begin{array}{l}11,47,48,68,69,83,84,90,91,92,113,114,115,116, \\
117,118,119,120,121,122,123,124 \\
48,67,68,82,83,84,85,90,91,92,113,114,116,117, \\
118,119,120,121,122,123,124 \\
62,63,64,65,66,98,110,111,112 \\
110,111\end{array}$ & $\begin{array}{l}63 \\
94 \\
32 \\
8\end{array}$ \\
\hline
\end{tabular}

This table shows that all the participants select the same strategies to vent their anger. It is a common human behavior. They alternate accusative charges and accompany them with the strategic use of direct address and indexical pronouns. Each one of them attempts to defend himself and to refute the other one. Failing to adapt to each other's psychological world, they use such strategies to blame each other. This wins them a psychological release. Unfortunately, they run in a marathon of loss and dirt where no one is to win.

\section{VII. b. 2. Bold Statements and Expletives:}

Other linguistic strategies of conflict talk that are used in Marriage Story are bold statements and expletives. Here, the conflicting parties give up the use of indirect polite language and target their anger directly towards their opponents. In so doings, they take off their gloves and stop using questions. Rather, they use bold declarative statements that carry all the negative terms about the other party. In most of the cases, bold statements are accompanied by expletives. Look at the following example. The physical world is Charlie's newly rented house in Los Angeles.

"Charlie: All your best acting is behind you (.) You're back to being a HACK (.)

Nicole: =You gaslighted me (.) You're a fucking villain (.)

Charlie: You want to present yourself as a victim because it's a good legal

strategy, FINE (.) But you and I both know you CHOSE this life (.)

You wanted it until you didn't (.)

((Nicole is silent. $))$ 
Nicole: You're so merged with your own selfishness that you don't even identify it as selfishness anymore (.) You're such a DICK (.)

Charlie: Every day I wake up and hope you're dead (.) Dead like (.)

((And then Charlie starts crying. Through tears $)$ )

\section{illness}

If I could guarantee Henry would be OK, I'd hope you get an

And then get hit by a car and DIE (.)" (Ibid, 123-124)

Here, conflict talk between Charlie and Nicole gets escalated to the extent that they cannot resume their marital life anymore. Perceiving this harsh reality, they produce bold statements that carry negative attributes towards each other. They fail to achieve adaption between the psychological world inside them that drags them towards fighting and the social world around them that sustains a good mutual rapport between spouses involved in interaction. Their divorce negotiations turn into a street fight. They use expletives in a way that makes them feel ashamed of themselves. Nicole calls Charlie fucking villain, selfish, and dick. On the other hand, Charlie calls Nicole a hack and wishes that she gets an illness and dies in a car accident. Neither is he nor she able to control his nerves. They lose their temper and throw accusative charges on each other by using bold statements that have expletives and second person indexical pronouns. They are trapped in their own structural and strategic patterns of interaction. They turn themselves into raptors.

The following table presents a summary of the use of bold statements and expletives between the disputing parties in Marriage Story.

Table (6)

Bold Statements and Expletives

\begin{tabular}{|c|c|c|c|}
\hline $\begin{array}{l}\text { Language } \\
\text { Users }\end{array}$ & Bold Statements and Negative terms & $\begin{array}{l}\text { Page } \\
\text { Number }\end{array}$ & $\begin{array}{l}\text { Frequen } \\
\text { cy }\end{array}$ \\
\hline Nicole & $\begin{array}{l}\text { I think I'll go if you two are just going to sit around and suck each } \\
\text { other's dicks! } \\
\text { We should probably do separate Halloweens (.) } \\
\text { You are a FUCKING LIAR (.) You fucked Mary Ann (.) } \\
\text { I'm conflating, motherfucker (.) Watch me conflate (.) } \\
\text { Me discovering you're fucking Mary Ann (.) } \\
\text { You put me through hell DURING the marriage! } \\
\text { No, you fuck off (.) }\end{array}$ & $\begin{array}{l}11 \\
84 \\
91 \\
92 \\
117 \\
119 \\
120\end{array}$ & $\begin{array}{l}1 \\
2 \\
1 \\
1 \\
1 \\
1\end{array}$ \\
\hline
\end{tabular}




\begin{tabular}{|c|c|c|c|}
\hline & $\begin{array}{l}\text { I repulsed when you touched me (.) ... The thought of having sex } \\
\text { with you makes me want to peel my skin off. } \\
\text { You gaslighted me (.) You're a fucking villain (.) } \\
\text { You're so merged with your own selfishness that you don't even } \\
\text { identify it as selfishness anymore (.) You're such a DICK (.) }\end{array}$ & $\begin{array}{l}121 \\
122 \\
124\end{array}$ & 2 \\
\hline Charlie & $\begin{array}{l}\text { Fuck Nora (.) I hate fucking Nora (.) } \\
\ldots \text { I needed my asshole! } \\
\ldots \text { You pulled the rug out from under me and you're putting me } \\
\text { through hell (-) } \\
\text { Oh, fuck off (.) } \\
\text { You're all the bad things about all of these people (.) ... } \\
\text { I look at you and see HER and just feel so GROSS (.) } \\
\text { You're a slob(.) I made all the beds, closed all the cabinets, picked up } \\
\text { after you like an infant (.)... } \\
\text { You just want fucking complain about not having a voice(.) } \\
\text { You're fucking insane! And you're fucking WINNING(.) } \\
\text { Everyday I wake up and hope you're dead (.) Dead like (.) ... I'd } \\
\text { hope you get an illness and then get hit by a car and DIE (.) }\end{array}$ & $\begin{array}{l} \\
120 \\
121 \\
122 \\
124\end{array}$ & 2 \\
\hline Jay & $\begin{array}{l}\text {...She's known as the girl in that college sex movie who takes her top } \\
\text { off (.) } \\
\text {... Nicole is withholding Henry, alienating him from his father(.) ...It } \\
\text { amounts to an ambush (.) }\end{array}$ & $\begin{array}{l}108 \\
110\end{array}$ & 1 \\
\hline Nora & $\begin{array}{l}\text { His genius was an intangible asset built during the marriage (.) } \\
\text { Those are fighting words and it is simply false and does nothing to } \\
\text { further our settlement (.) Your recap of this situation is outrageous (.) }\end{array}$ & 109 & 1 \\
\hline
\end{tabular}

This table shows that all the participants are responsible for the divorce. None of them is really willing to save this marriage. Whenever they talk, they manipulate language choice in a manner that achieves adaptation to their own psychological and social worlds. They use language to shoot each other and to spotlight on the negative attributes that do not even exist. They do so just to win the custody. They forget that the real win is their son's benefit. In fact, we cannot sympathize with one party against the other. Both parties are making mistakes.

\section{VII. b. 3. Negation:}

Negation is another strategic process that accompanies conflict talk. Whenever people have opposing views, they always use the polar negation 'no', the negative 'not' in addition to all other negative affixes to deny whatever is said to them. This is exactly what occurs between Nicole and Charlie during their divorce negotiations. Look at the following extract. The physical world is Charlie's house in Los Angeles.

" $\rightarrow$ Nicole: The only reason we didn't live here was because you can't imagine desires other than your own unless they're forced on you (.)

$\rightarrow$ Charlie: Ok, you wish you hadn't married me, you wish you'd had a different life (.) But this is what happened (.) 
$\ldots$

Nicole: And now you're going to put Henry through this horrible thing so You can yet again get what you want (.)

$\rightarrow$ Charlie: It's not what I want (-) I mean. It's what I want, but it's what was (-) WAS (-) what's best for him (.)

Nicole: I was wondering when you'd get around to Henry and what HE actually wants (.)

Charlie: Oh, fuck you (.)

$\rightarrow$ Nicole: =No:: , you fuck off (.)" (Ibid: 118- 120)

Here, Nicole and Charlie are engaged in their last big fight. Their haughtiness, stubbornness, and selfishness make their conflict talk gets escalated from 'oppositional disagreements' into 'disputes'. Nicole uses bold statements, indexical second person pronouns, and negation to accuse Charlie and assign him responsible for the failure of their marriage. In response, Charlie manipulates the same linguistic strategies to defend himself and to fight her back. Moreover, he starts using the expletive 'fuck you'. In turn, Nicole uses the most common opposition marker, the polar 'no', and follows it with another expletive 'you fuck off'. Thus, their talk turns into an endless cycle of conflicts.

The following table sums up the use of negation in Marriage Story. Negation includes: the polar 'no', the negative marker 'not', negative adverbs such as 'never, hardly, etc.' and the negative affixes as well.

Table (7)

Negation

\begin{tabular}{|c|c|c|}
\hline $\begin{array}{l}\text { Language } \\
\text { Users }\end{array}$ & Page Number & Frequency \\
\hline Nicole & $\begin{array}{l}10,16,31,32,33,34,35,36,48,49,69,83,85,91,92,113,116, \\
117,118,119,120,121,122,123,124,128,129\end{array}$ & 69 \\
\hline Charlie & $\begin{array}{l}10,16,48,49,54,55,56,62,63,64,65,67,68,69,79,83,84,91, \\
92,98,113,114,116,117,118,119,120,121,122,123\end{array}$ & 77 \\
\hline & $31,32,33,62,64,65,66,69,108,109,110,111,128,129$ & 28 \\
\hline Bert & $79,80,95,98$ & 11 \\
\hline Jay & $54,56,108,109,110,111$ & 8 \\
\hline
\end{tabular}

This table shows that negation is a major linguistic strategy which is used excessively in conflict talk. All the fighting members use it to index their disagreement and opposition. They insist on opposition and refuse mitigation. 
To recap, the following table sums up the frequency of the linguistic strategies of conflict talk between Nicole's party and Charlie's party.

Table (8)

Linguistic Strategies of Conflict Talk

\begin{tabular}{|l|l|l|}
\hline Linguistic Straegies & Nicole's Party & Charlie's Party \\
\hline Direct Address and Second Person Indexical Pronouns & 101 & 106 \\
Bold Statements and Expletives & 16 & \\
Negation & 97 & 17 \\
& & 96 \\
\hline Total & 214 & 219 \\
\hline
\end{tabular}

As this table shows, both parties are nearly very close in their use of the linguistic strategies of conflict talk. That is why we find ourselves unable to take one side against the other one. Both parties are stepping in the moors of shame and disgust. Instead of figuring things out peacefully, they turned their divorce negotiations into street fights where they turned into severe raptors. Their only aim is to win the fight of custody, regardless of any negative consequences. So, they put a sad end to their marriage story.

\section{Conclusion:}

This research paper studied conflict talk in Noah Baumbach's Marriage Story. It showed that conflict talk is a complicated process of constant dynamic negotiations between the disputing people. It offered an interdisciplinary study of the challenging negotiations of divorce between Nicole and Charlie. It showed that marriage is not always the expected end of love stories. Rather, divorce can be the sad end of these love stories. The paper followed Verscheuren's pragmatic theory of adaptation in the analysis of data. It showed that the adaptation theory is worthy for the study of conflict talk. In the light of this theory, the paper pinpointed the following causes for conflict talk:

1)The physical world is a very significant purpose of conflict between the couples. Charlie wants to stay in New York whereas Nicole wants to go back to Los Angeles and to stay there. Both refuse to adapt to each other's physical world.

2)Charlie and Nicole's failure to adapt to each other's psychological world initiates and escalates the conflict between them. They manipulate language choice in a way that does not bridge the gap between their inner thoughts. Each one adapts a different frame of communication.

3)Not only does the lack of adaptability to various situations in the world escalate conflict, but adaptability leads to the same end in some cases, namely, the irony. When language users adapt to each other's 
psychological world and understand their intentions, they interpret the friendly utterance as an offensive act of irony. Therefore, they adapt their behaviors towards conflicting and divergent responses.

4) Language users involved in conflict talk must be alert to their strategic choices. If they do not adapt their behavior to their linguistic choices, with respect to the conventions of the social world around them, they will lose control of the interaction. They will be trapped in their structural and strategic patterns of interaction.

The paper concludes that life, in general, and marriage, in specific, are never free from conflicts. It is up to the spouses to figure out adaptive and convergent resolutions to them. They must learn how to talk about these conflicts to terminate them. Still more work is needed on the resolution of conflict talk between members in society as well as between nations. Also, we are still in need of more empirical work on conflict talk.

\section{References:}

1. Antaki, C. 1994. Explaining and Arguing: the Social Organization of Accounts. London: Sage.

2. Baumbach, N., director and writer.2019. Marriage Story. http://pmcdedline2.files.wordpress.com/2019/12/marriage -storyampas-script.pdf

3. Ball, C. 1991. The historical development of the it-cleft. Unpublished doctoral dissertation. University of Pennsylvania.

4. Baym, N. 1996. 'Agreements and disagreements in a computermediated discussion'. In Research on Language and Social Interaction, 29: 315-345.

5. Biber, D. 1988. Variation across Speech and Writing. Cambridge: Cambridge University Press.

6. Biber, D. and Finegan, E. 1989. 'Styles of stance in English: lexical and grammatical marking of evidentiality and affect'. In Text, 9 (1): 93-124.

7. Bilmes, Jack. 1988. "The concept of preference in conversation analysis'. In Language in Society, 17: 161-181.

8. Boggs, S. 1978. 'The development of verbal disputing in partHawaiian children'. In Language in Society, 7: 325- 344.

9. Brennis, D. and Lein, L. 1977. 'You fruithead: a sociolinguistic approach to children's dispute settlement'. In Child Discourse. ErvinTripp, S. and Mitchel-Kernan, C., eds. New York: Academic Press.

10. Briggs, C., ed. 1996. Disorderly Discourse: Narrative, Conflict, and Inequality. Oxford: New York. 
11. Brown, P. 1990. 'Gender, politeness, and confrontation in Tenejapa'. In Discourse Processes, 13: 123- 141.

12. Clayman, S. 1993. 'Reformulating the question: a device for answering / not answering questions in interviews and press conferences'. In Text, 13 (2): 159-188.

13. Collins, P. 1991. Cleft and Pseudo- Cleft Constructions in English. London/ New York: Routledge.

14. Connor- Linton, J. 1989. Crosstalk: a multi- feature analysis of SovietAmerican spacebridges. Unpublished doctoral dissertation. University of Southern California.

15. Cortini, M. 2001. 'Silence as a tool for the negotiation of sense in multi-party conversations'. In Negotiation and Power in Dialogic Interaction. Weigand, E. and Dascal, M., eds. Amsterdam: John Benjamin Company.

16. Declerk, R. 2011. Studies on Copular Sentences, Clefts and PseudoClefts. Walter De Gruyter.

17. Declerk, R. 1984. 'The pragmatics of it-clefts and wh-clefts'. In Linua, 64: 251-289.

18. Delin, J. 2000. The Language of Everyday Life. London: Sage Publications.

19. Dersley,I. and Wootton, A. 2001. 'In the heat of the sequence: interactional features receding walkouts from argumentative talk'. In Language in Society, 30: 611- 639.

20. Deutsch, M. 1973. The Resolution of Conflict: Constructive and Destructive Processes. New Haven, CT: Yale University Press.

21. Dews, S. et al. 1995. 'Why not say it directly? The social functions of irony'. In Discourse Processes, 19: 347- 367.

22. Drake, L. and Donohue, W. 1996. 'Communicative framing theory in conflict resolution'. In Communication Research, 23: 297-322.

23. Drew, P. and Heritage, J., eds. 1992. Talk at Work: Interaction in Institutional Settings. Cambridge: Cambridge University Press.

24. Eisenberg, A. and Garvey, C. 1981. 'Children's use of verbal strategies in resolving conflicts'. In Discourse Processes, 4: 149-67.

25. Folger, J., et. al. 1997. Strategies for Relationships, Groups, and Organizations: Working through Conflict. Longman.

26. Fraser, B. 2001. 'The mediator as power broker'. In Negotiation and Power in Dialogic Interaction. Weigand, E. and Dascal, M., eds. Amsterdam: John Benjamin Company. 
27. Galasinski, D. 2000. The Language of Deception: a Discourse Analytic Study. Sage Publications, Inc.

28. Galasinski, D. 1996. 'Deceptiveness of evasion'. In Text, 16 (1): 1-22.

29. Georgakopoulou, A. 2001. 'Arguing about the future: on direct disagreement in conversations'. In Journal of Pragmatics, 33: 18811990.

30. Giles, H.,et al. 1987. 'Speech accommodation theory: the first decade and beyond'. In Mclaughlin, M. ed. Communication Yearbook, 10: 1340. Beverly Hills,CA: Sage.

31. Gita, A. 2001. 'Negotiation of irony in dialogue'. In Negotiation and Power in Dialogic Interaction. Weigand, E. and Dascal, M., eds. Amsterdam: John Benjamin Company.

32. Goffman, E. 1974. Frame Analysis. New York: Harper and Row.

33. Goodwin, M. 2006. 'Participation, affect, and trajectory in family directive/ response sequences'. In Text and Talk. Walter de Gruyter, 26 (4/4): 513-541.

34. Goodwin, M. 1990a. He -Said-She-Said: Talk as Social Organization among Black Children. Bloomington: Indiana University Press.

35. Goodwin, M. 1990b. 'Tactical use of stories participation frameworks within girls' and boys' disputes'. In Discourse Processes, 13: 33- 71.

36. Goodwin, M. 1983. 'Aggravated corrections and disagreements in children's conversations'. In Journal of Pragmatics, 7: 657- 677.

37. Goodwin, M. and Goodwin, C. 1990. 'Interstitial arguments'. In Conflict Talk: Sociolinguistic Investigations of Arguments in Conversations. Grimshaw, A. ed. Cambridge: Cambridge University Press.

38. Goodwin, M. and Goodwin, C. 1987. 'Children's arguing'. In Language, Gender, and Sex in Comparative Perspective. Philip, S. et. al, eds. Cambridge: Cambridge University Press.

39. Gracia, A. 1991. 'Dispute resolution without disputing: how the interactional organization of hearings minimizes argument'. In American Sociological Review, 56: 818- 835.

40. Greatbatch, D. and Gingwall, R. 1997. 'Argumentative talk in divorce mediation sessions'. In American Sociological Review, 62: 151-170.

41. Greatbatch, D. 1992. 'On the management of disagreement between news interviewees'. In Talk at Work: Interaction in Institutional Settings. Drew, P. and Heritage, J.,eds. Cambridge: Cambridge University Press. 
42. Grimshaw, A. 1990. Conflict Talk: Sociolinguistic Investigations of Arguments in Conversations. Cambridge: Cambridge University Press.

43. Halliday, M. 1985. An Introduction to Functional Grammar. London: Edward Arnold.

44. Halliday, M. 1982. 'A short introduction to functional grammar'. In Linguistics Dept., University of Sydney.

45. Halliday, M. 1967. 'Notes on transitivity and theme in English'. In Journal of Linguistics, 3 (2): 199-244.

46. Harris, S. 1984. 'Questions as a mode of control in magistrates' courts'. In International Journal of the Sociology of Language, 49: 527.

47. Heritage, J. 2002. 'The limits of questioning: negative interrogatives and the hostile question content'. In Journal of Pragmatics, 34: 14271446.

48. Hocker, J. and Wilmot, W. 1991. Interpersonal Conflict. Dubuque: William C. Brown.

49. Hymes, D. 1974. Foundations in Sociolinguistics: an Enthnographic Approach . Philadelphia, PA: University of Pennsylvania Press.

50. Infant, D. and Rancer, A. 1996. 'Argumentativeness and verbal aggressiveness: a review of recent theory and research'. In Communication Yearbook, 19: 319- 351.

51. Jefferson, G. 1981. 'The rejection of advice: managing the problematic convergence of a trouble's telling and a service encounter'. In Journal of Pragmatics, 5: 399-422.

52. Kakava, C. 2001. 'Discourse and conflict'. In The Handbook of Discourse Analysis. Schiffrin, D. and Hamilton, H., eds. Blackwell Publishers, Ltd.

53. Klerk, V. 1997. 'The role of expletives in the construction of masculinity'. In Johnson, S. and Meinhof, U. eds. Language and Masculinity. Blackwell Publishers.

54. Kotthoff, H. 1993. 'Disagreement and concession in disputes: on the context sensitivity of preference structures'. In Language in Society, 22: 193- 216.

55. Krainer, E. 1988. 'Challenges in psychotherapy group'. In Proceegings of the fourteenth Annual Meeting of the Berkeley Linguistics Society. Axmaker, S., et al., eds. Berkeley,CA: Berkeley Linguistics Society.

56. Leech, G. 1991. Principles of Pragmatics. London: Longman. 
57. Liedtke, F. 2001. 'The negotiation of relevance'. In Negotiation and Power in Dialogic Interaction. Weigand, E. and Dascal, M., eds. Amsterdam: John Benjamin Company.

58. Maier, R. 2001. 'Negotiation and identity'. In Negotiation and Power in Dialogic Interaction. Weigand, E. and Dascal, M., eds. Amsterdam: John Benjamin Company.

59. Maynard, D. 1985a. 'How children start arguments'. In Language in Society, 14: 1- 30.

60. Myers, G. 1998. 'Displaying opinions: topics and disagreement in focus groups'. In Language in Society, 27: 85- 111.

61. Nelson, C. 2001. 'If it sounds too good to be true, it is: a Wittengrnsteinian approach to the conflict literature'. In Language and Communication, 21: 1-22.

62. Nickerson, R. 2015. Conditional Reasoning: the Unruly Syntactics, semantics, and Pragmatics of If. Oxford: Oxford Press.

63. Oberlander, J. and Delin, J. 1996. 'The function and interpretation of reverse wh-clefts in spoken discourse'. In Language and Speech, 39 (2/3): 185-227. London: Kingston Press Services.

64. Ochs, E. 1979. 'Transcription as theory'. In Developmental Pragmatics. Ochs, E. and Scheffelin, B. eds. New York: Academic Press.

65. Pomerantz, A. 1984a. 'Agreeing and disagreeing with assessments: some features of preferred/ dispreferred turn structures'. In Structures of Social Action: Studies in Conversation Analysis. Atkinson, J. and Heritage, J., eds. Cambridge: Cambridge University Press.

66. Rees- Miller, J. 2000. 'Power, severity and context in disagreement'. In Journal of Pragmatics, 4: 341- 350.

67. Rehbein, J. 1995. 'International sales talk'. In The Discourse of Business Negotiation. Ehlich and Wagner, eds. 1995. Berlin and New York: Mouton de Gruyter.

68. Rooij, R. and Franke, M. 2012. 'Promises and threats with conditionals and disjunctions'. In Discourse and Grammar: from sentence Types to Lexical Categories. Grewendorf, G. and Zimmermann, T., eds. Berlin: De Gruyter Mouton.

69. Schiffrin, D. 1985. 'Everyday argument: the organization of diversity in talk'. In A Handbook of Discourse Analysis. van Dijk, T., ed. London: Academic Press.

70. Scott, S. 2002. 'Linguistic feature variation within disagreements: an empirical investigation'. In Text. Walter de Gruyter, 22 (2): 301- 328. 
71. Sperber, D. and Wilson, D. 1981. 'Irony and the use- mention distinction'. In Radical Pragmatics. Cole, E., ed. New York: Academic Press.

72. Stubbs, M. 1983. Discourse Analysis. Oxford: Basil Blackwell.

73. Ugwu, R. 2019. 'Marriage Story: autobiographical or personal? Noah Baumbach explains' In New York Times, Nov. 27, 2019.

74. Van Leeuwen, T. and Wodak, R. 1999. 'Legitimizing immigration control: a discourse historical analysis'. In Discourse Studies, 1 (1): 83-118.

75. Verschueren, J. 1999. Understanding Pragmatics. London: Arnold.

76. Wehr, P. 1979. Conflict Regulation. Boulder, CO: Westview.

77. Wood, L. and Kroger, R. 1994. 'The analysis of face work in discourse: review and proposal'. In Journal of Language and Social Psychology. Sage Publications, 13 (3): 248-277.

78. Xiyuan, J. 2018. 'A pragmatic study of mitigating strategies for interpersonal conflicts in unequal power relations'. In International Journal of Language and Linguistics, 6 (4): 118- 126. 